DOI: https://doi.org/10.18371/fp.3(39).2020.215147

УДК 338.336

\title{
ВИКОРИСТАННЯ КЛАСТЕРНОГО АНАЛІЗУ ДЛЯ ВИЗНАЧЕННЯ РІВНЯ ФІНАНСОВОÏ СТІЙКОСТІ ПІДПРИЄМСТВ
}

\author{
ТРЕТЯК Наталя Миколаївна \\ кандидат економічних наук, доцент \\ дочент кафедри фінансів та банківської справи \\ Черкаського навчально-наукового інституту \\ Університету банківської справи \\ ORCID ID: http://orcid.org/0000-0002-9457-2645 \\ e-mail:natali_m2008@ukr.net
}

\section{ГОЛОВКО Олена Григорівна}

кандидат економічних наук, доцент,

Харківський національний університет імені В.Н. Каразіна

ORCID ID: http://orcid.org/0000-0001-6502-4562

e-mail: elena.golovko13@gmail.com;

\section{ЖЕВАГО Діана Миколаївна}

магістр Харківський національний університет імені В.Н. Каразіна

e-mail: bankovskayahibs20@gmail.com

Анотація. У статті вирішується важливе науково-практичне завдання, щуо полягає в обтрунтуванні теоретичних аспектів та розробиі практичних рекомендацій щуодо удосконалення прочесу управління фінансовою стійкістю як складовою забезпечення стійкого функиіонування підприємств харчової галузі. Розглядається механізм управління фінансовою стійкістю підприємства, задля виявлення критичної оцінки фінансових результатів як у статиці за певний період, так $i$ в динаміці. $B$ роботі представлений всебічний аналіз функціонування підприємств харчової галузі з визначенням рівня ефективності управління їх фінансовою стійкості.

Ключові слова: фінансова стійкість, ефрективність управління, кластерний аналіз, фінансові ресурси, алгоритми обчислення, фінансові коефіиієнти.
Аннотация. $B$ cmaтье решается важная научно-практическая задача, заключающияся в обосновании теоретических аспектов и разработке практических рекомендаций по совершенствованию прочесса управления финансовой устойчивостью как составляющей обеспечения устойчивого функиионирования предприятий пищевой отрасли. Исследуется механизм управления финансовой устойчивостью предприятия, направленный на выявление критической оченки финансовых результатов как в статике за определенный период, так и в динамике. В работе представлен всесторонний анализ функционирования предприятий пищевой отрасли с определением уровня эффективности управления их финансовой устойчивости.

Ключевые слова: финансовая устойчивость, эффективность управления, кластерный анализ, финансовые ресурсы, алгоритмы вычисления, финансовые коэффициенты. 
Постановка проблеми. Фінансова стійкість харчової промисловості передбачає здатність підприємства зберігати заданий режим функціонування за найважливішими фінансовоекономічними показниками.

На сьогодні харчова промисловість $€$ однією із провідних галузей вітчизняної економіки. Вона безпосередньо задіяна в забезпеченні продовольчої безпеки держави, формуванні ії експортного потенціалу й здатна позитивно впливати на динаміку економічного зростання України. Діяльність харчової промисловості, що ефективно, високопродуктивно, динамічно зростає є пріоритетом у забезпеченні економічної безпеки держави і досягненні високої національної конкурентоздатності. I тому, фінансова стійкість харчової промисловості має характеризуватися таким станом фінансових ресурсів, який відповідає вимогам ринку, а їхній розподіл і використання мають забезпечувати розвиток підприємства на основі зростання прибутку й капіталу при збереженні платоспроможності в умовах допустимого рівня ризику. Фінансова стійкість харчового підприємства є ключовою ознакою його фінансового стану та стратегічного розвитку.

Виклики сьогоденності потребують здійснення аналізу фінансової стійкості 3 використанням економічних моделей, що створює для підприємства нові можливості з виявлення резервів стосовно підвищення конкурентної позиції, до збільшення долі ринку та виконання інших тактичних та стратегічних цілей. Зараз, коли підприємствам потрібно втримувати свої позиції на конкурентному ринку, фінансова стійкість та іï постійний моніторинг $є$ пріоритетним питанням, яке потребує управлінського вирішення.

Аналіз останніх досліджень і публікацій. Проблемі управління фінансовою стійкістю підприємств приділяється багато уваги як у міжнародній, так і у вітчизняній теорії та практиці. Зокрема, важливе місце в дослідженні даного питання посідають праці ученихекономістів Бланка I.О., Брігхема С.Ф., Долана Е.Дж., Шеремета А.Д., Хелферта Е. та ін. Вирішення цієї проблеми також знайшло відображення в роботах Белікової Т.В., Ващенка Л.О., Забродського В.А., Кизима М.О., Колесникової В.М., Савицької Г.В., Терещенка О.О., Мірошника О.Ю., Азаренкової Г.М., Головко О.Г., Гур'янової Л.С. та ін. Останніми роками дедалі більше праць присвячується аналізу фінансової стійкості, однак більшість літературних джерел $з$ цієї проблематики обмежена лише розглядом системи показників та алгоритмів їх розрахунку, і невиправдано залишаються поза увагою інші важливі аспекти даної тематики. Досі, не в повній мірі розглянуто питання взаємозв'язку, що існує між фінансовою стійкістю та іншими характеристиками фінансового стану підприємства.

Метою статті $\epsilon$ проведення кластеризації підприємств за рівнем їх фінансової стійкості на прикладі підприємств харчової промисловості.

Результати дослідження. Фінансова стійкість підприємства $є$ однією 3 провідних умов стабільного розвитку й забезпечення високого рівня конкурентоспроможності підприємства. На думку Кіндрат О.В., фінансова стійкість передбачає, що фінансові ресурси вкладе- 
ні в господарську діяльність, мають окупитися за рахунок грошових надходжень від неї, а отриманий прибуток повинен забезпечити самофінансування та незалежність підприємства від зовнішніх залучених джерел формування активів [5, с.217].

Кластерний аналіз - це сукупність методів, що дозволяють згрупувати багатовимірні спостереження, кожне 3 яких описується набором вихідних змінних. Поняття кластеризації походить від англійського слова «cluster», що означає гроно, скупчення, група. Вперше предмет кластерного аналізу був визначений в 1939 році дослідником Тріоном. На відміну від комбінаційних угрупувань, такий аналіз призводить до розбиття на групи з урахуванням всіх групувальних ознак одночасно [1]. Основою такого аналізу є набір різноманітних методів і алгоритмів класифікації, тобто методів об’єднання кластерів.

Кластерний аналіз передбачає проведення вибірки об'єктів для кластерізаціï, визначення множинних ознак, за якими будуть оцінюватися відібрані об'єкти, оцінка міри подібності об'єктів, застосування такого аналізу для створення груп подібних об'єктів, перевірка достовірності результатів аналізу [4].

Задля проведення кластерного аналізу було сформовано вибірку з 10 підприємств харчової промисловості Украї- ни, зокрема підприємств, які виробляють напої (табл. 1).

На підставі офіційних даних фінансової звітності підприємств - виробників пива за 2018 рік розраховані показники, які характеризують фінансову стійкість підприємства, зокрема коефіцієнт автономії, фінансового ризику, маневреності власного капіталу, фінансового левериджу. Розраховані показники фінансової стійкості за 2018 рік представлено у табл. 2. На основі отриманих даних було проведено кластерізацію підприємств харчової промисловості України, виробників напоїв за 2018 рік за рівнем їх фінансової стійкості.

Для визначення оптимальної кількості кластерів серед досліджуваних підприємств використано один 3 ієрархічних методів - метод Уорда. У цьому методі в якості цільової функції застосовують внурішньогрупову суму квадратів відхилень, яка $\epsilon$ не що інше, як сума квадратів відстаней між кожною точкою (об'єктом) і середньої по кластеру, містить цей об'єкт.

Проведення кластерного аналізу запропоновано робити 3 використання програмного продукту «Statistika».

Показники, які $є$ необхідними для розрахунку рівня фінансової стійкості підприємств, а також проведення кластеризації таких підприємств представлено на рис. 1. 
Таблиця 1

Вибірка підприємств харчової промисловості України, виробників напоїв

\begin{tabular}{|c|c|c|c|c|}
\hline № $3 /$ П & Назва підприємства & Регіон & КВЕД & Вид діяльності \\
\hline 1 & ПрАТ «АБІНБЕВЕФЕС УКРАЇНА» & м.Київ & 11.05 & Виробництво пива \\
\hline 2 & ПрАТ «КАРЛСБЕРГ УКРАЇНА» & Запорізька обл. & 11.05 & Виробництво пива \\
\hline 3 & ПрАТ «ОБОЛОНЬ» & м.Київ & 11.05 & Виробництво пива \\
\hline 4 & ПрАТ «ОПІЛЛЯ» & $\begin{array}{l}\text { Тернопільська } \\
\text { обл. }\end{array}$ & 11.05 & Виробництво пива \\
\hline 5 & ПрАТ «ПОЛТАВПИВО» & Полтавська обл. & 11.05 & Виробництво пива \\
\hline 6 & $\begin{array}{c}\text { TOB «Перша приватна броварня. Для } \\
\text { людей - як для себе!» }\end{array}$ & Львівська обл. & 11.05 & Виробництво пива \\
\hline 7 & ПрАТ «Уманьпиво» & Черкаська обл. & 11.05 & Виробництво пива \\
\hline 8 & $\begin{array}{c}\text { ПрАТ «МИКУЛИНЕЦЬКИЙ БРО- } \\
\text { ВАР» }\end{array}$ & $\begin{array}{l}\text { Тернопільська } \\
\text { обл. }\end{array}$ & 11.05 & Виробництво пива \\
\hline 9 & $\begin{array}{c}\text { ПрАТ «Пиво-безалкогольний комбі- } \\
\text { нат. Радомишль» }\end{array}$ & $\begin{array}{l}\text { Житомирська } \\
\text { обл. }\end{array}$ & 11.05 & Виробництво пива \\
\hline 10 & $\begin{array}{c}\text { ПрАТ «Славутський пивоварний за- } \\
\text { вод» }\end{array}$ & $\begin{array}{l}\text { Хмельницька } \\
\text { обл. }\end{array}$ & 11.05 & Виробництво пива \\
\hline
\end{tabular}

Джерело: розраховано авторами за даними[7-16]

Таблиця 2

Показники фінансової стійкості підприємств харчової промисловості України за 2018 рік

\begin{tabular}{|c|c|c|c|c|c|}
\hline \multirow[b]{2}{*}{$\begin{array}{l}\text { № } \\
3 / \Pi\end{array}$} & \multirow[b]{2}{*}{ Назва підприємства } & \multicolumn{4}{|c|}{ Фінансові показники } \\
\hline & & $\begin{array}{r}\text { Коефіцієнт } \\
\text { автономії }\end{array}$ & $\begin{array}{c}\text { Коефіцієнт } \\
\text { фінансового } \\
\text { ризику }\end{array}$ & $\begin{array}{c}\text { Коефіцієнт манев- } \\
\text { реності власного } \\
\text { капіталу }\end{array}$ & $\begin{array}{c}\text { Коефіцієнт } \\
\text { фінансового } \\
\text { левериджу }\end{array}$ \\
\hline 1 & 2 & 3 & 4 & 5 & 6 \\
\hline 1 & $\begin{array}{c}\text { ПрАТ «АБІНБЕВЕФЕС УКРАЇ- } \\
\text { НА» }\end{array}$ & 0,13 & 3,38 & $-4,81$ & 4,35 \\
\hline 2 & ПрАТ «КАРЛСБЕРГ УКРАЇНА» & 0,58 & 0,73 & 0,33 & 0,73 \\
\hline 3 & ПрАТ «ОБОЛОНЬ» & 0,36 & 1,81 & $-1,22$ & 1,81 \\
\hline 4 & ПрАТ «ОПІЛЛЯ» & 0,38 & 1,63 & $-1,62$ & 1,63 \\
\hline 5 & ПрАТ «ПОЛТАВПИВО» & 0,56 & 0,78 & 0,12 & 0,78 \\
\hline 6 & $\begin{array}{c}\text { TOВ «Перша приватна броварня. } \\
\text { Для людей - як для себе!» }\end{array}$ & 0,61 & 0,65 & 0,18 & 0,78 \\
\hline 7 & ПрАТ «Уманьпиво» & 0,69 & 0,74 & 0,17 & 0,72 \\
\hline 8 & $\begin{array}{c}\text { ПрАТ «МИКУЛИНЕЦЬКИЙ } \\
\text { БРОВАР» }\end{array}$ & 0,74 & 0,53 & 0,19 & 0,71 \\
\hline 9 & $\begin{array}{c}\text { ПрАТ «Пиво-безалкогольний } \\
\text { комбінат. Радомишль» }\end{array}$ & 0,66 & 0,72 & 0,14 & 0,69 \\
\hline 10 & $\begin{array}{c}\text { ПрАТ «Славутський пивоварний } \\
\text { завод» }\end{array}$ & 0,59 & 0,77 & 0,15 & 0,73 \\
\hline
\end{tabular}

Джерело: розраховано авторами за даними[7-18] 


\begin{tabular}{|c|c|c|c|c|c|c|c|c|c|c|}
\hline \multirow[b]{2}{*}{ Case $\mathrm{Na}_{2}$} & \multicolumn{10}{|c|}{ Euclidean distances (Spreadsheet2) } \\
\hline & $\begin{array}{l}\text { ПАТ "САH } \\
\text { ІнБев } \\
\text { Україна" }\end{array}$ & $\begin{array}{c}\text { ПрАT } \\
\text { KAPICEEPT } \\
\text { УKPAIHAs }\end{array}$ & $\begin{array}{c}\text { ПрАТ } \\
\text { 'ObОПОНb' }\end{array}$ & $\begin{array}{l}\text { ПрАТ } \\
\text { оППППЯ: }\end{array}$ & $\begin{array}{c}\text { ПрAT "OPMA } \\
\text { "TOMIIATMB } \\
0^{\circ}\end{array}$ & 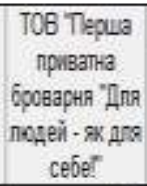 & $\begin{array}{c}\text { ПрАТ } \\
\text { Yмaньпиво" }\end{array}$ & $\begin{array}{c}\text { ПрАТ } \\
\text { 'МИКУЛИНЕLЬ } \\
\text { КМЙ БРОВАР" }\end{array}$ & $\begin{array}{c}\text { ПрАТ } \\
\text { "Пиво-безаnког } \\
\text { опьний } \\
\text { коибиат" Радо } \\
\text { мициь" }\end{array}$ & $\begin{array}{c}\text { ПрАТ } \\
\text { "Славутсыкй } \\
\text { пивоварнай } \\
\text { завод" }\end{array}$ \\
\hline ПАТ "CAH labeв Y'kpaī & 0,00 & 5,90 & 3,79 & 3,89 & 5,74 & 5,94 & 6,11 & 6.37 & 6,05 & 5,84 \\
\hline ПрАТ ККАРЛСБЕРГ УКРА & $5,90^{\circ}$ & 0,00 & 2,18 & 2,06 & 0,17 & 0,21 & 0,60 & 089 & 0,45 & 0,13 \\
\hline ПمАТ OEБОЛOH'? & 3,79 & 2,18 & 0,00 & 0,38 & 2,03 & 2,27 & 2,51 & 283 & 2,42 & 2,14 \\
\hline ПDAT 'ONIIT/ & 3.89 & 2,06 & 0,38 & 0,00 & 1,90 & 2,13 & 2,37 & 268 & 2,27 & 2,01 \\
\hline ПрАТ "ФPMA "TOMTABT & 5,74 & 0,17 & 203 & 190 & 0,00 & 0,29 & 0,68 & 099 & 0,53 & 0,15 \\
\hline TOB Териаз приватна & 5.94 & 0,21 & 227 & 2,13 & 0.29 & 0,00 & 0,44 & 0.71 & 0,29 & 0,18 \\
\hline ПрАТ 'Уманьпиво & 6,11 & 0,60 & 2,51 & 237 & 0,68 & 0,44 & 0,00 & 0,36 & 0,17 & 0,54 \\
\hline ПрАТ "МИКИТИНЕЦLЬКИЙ & 6,37 & 0,89 & 283 & 2.68 & 0,99 & 0,71 & 0,36 & 0,00 & 0,48 & 0,85 \\
\hline ПрАТ "Пиво-безапкого & 6,05 & 0,45 & 242 & 227 & 0,53 & 0,29 & 0,17 & 0.48 & 0,00 & 0,38 \\
\hline ПрАТ "Славулська па & 5,84 & 0,13 & 2.14 & 201 & 0,15 & 0,18 & 0,54 & 0.85 & 0,38 & 0,00 \\
\hline
\end{tabular}

Рис. 1. Евклідові відстані між об’єктами спостереження за методом Уорда Дюсерело: розроблено за допомогою програми «Statistika»

Дендрограма класифікації підпри- виробників напоїв за методом Уорда ємств харчової промисловості України, представлена на рис. 2.

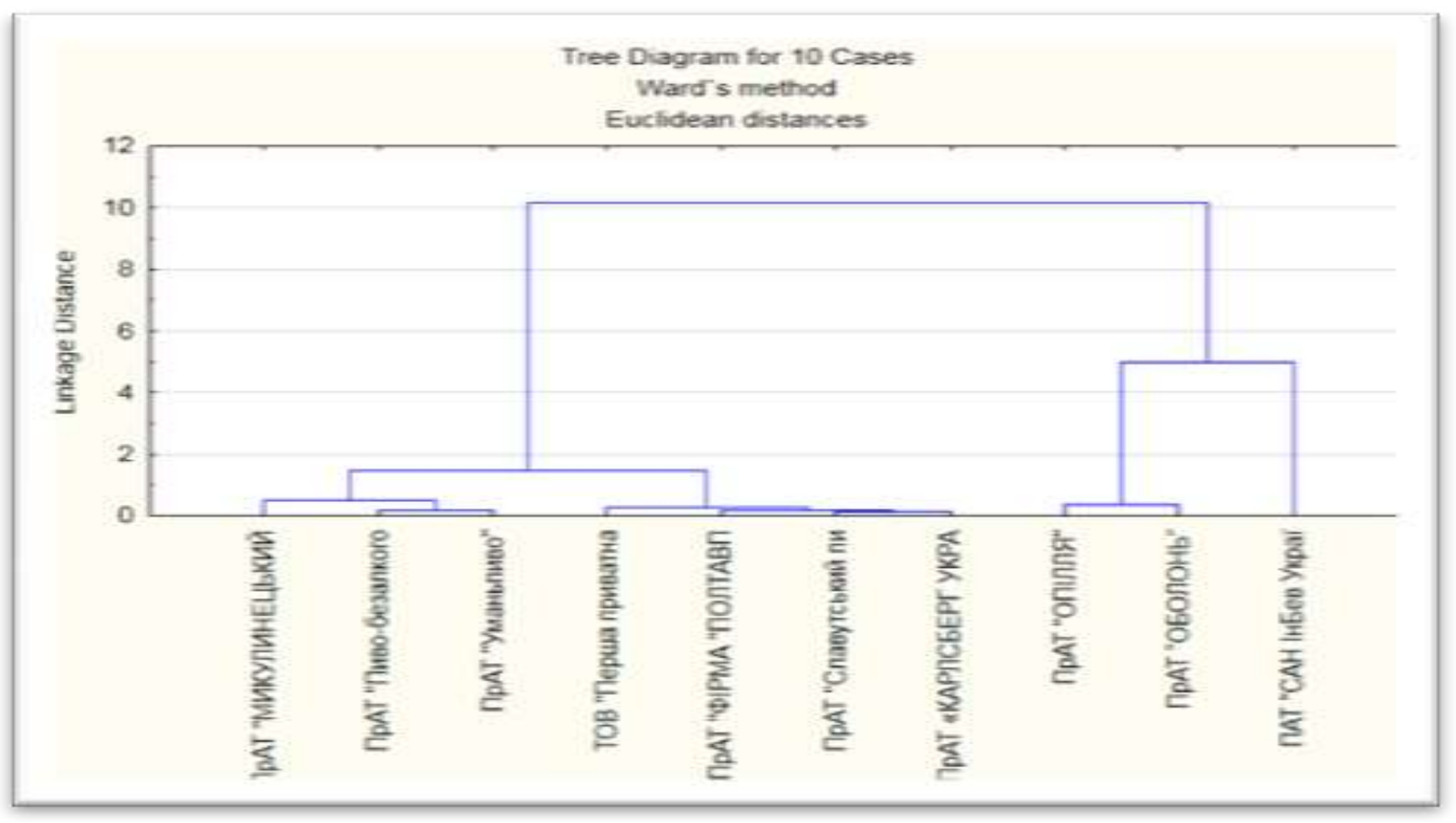

Рис. 2. Дендрограма кластерізації підприємств харчової промисловості України , виробників напоїв за методом Уорда Джерело: розроблено за допомогою програми «Statistika» 
Кластерізація дозволяє систематизувати об'єкти не за однією ознакою, а за декількома одночасно, приміром показники фінансової стійкості. Згідно з даними рис. 3 сформовано два кластери, перший кластер групує підприємства, які за показниками фінансової стійкості відповідають нормативним значенням, до другого кластеру відносяться підприємства, аналіз фінансової стійкості яких показав, що їх діяльність $є$ фінансово нестійкою.

До першого кластеру слід віднести ПрАТ «КАРЛСБЕРГ УКРАЇНА», ПрАТ «ФІРМА «ПОЛТАВПИВО», ТОВ «Перша приватна броварня «Для людей як для себе!», ПрАТ «Уманьпиво», ПрАТ «МИКУЛИНЕЦЬКИЙ БРОВАР», ПрАТ «Пиво-безалкогольний комбінат» Радомишль» та ПрАТ «Славутський пивоварний завод».

До другого кластеру слід віднести ПрАТ «АБІНБЕВЕФЕС УКРАЇНА»,
ПрАТ «ОБОЛОНЬ» та ПрАТ «ОПІЛЛЯ».

Для підтвердження отриманих результатів стосовно кластерного аналізу використаємо метод k-середніх. Широке застосування для задач кластеризації 3 великою кількістю вхідної інформації одержав метод k-середніх [2, c.10]. Цей метод кластеризації істотно різниться від подібних агломеративних методів, як деревоподібна кластеризація. Названий метод розв'язує такі типи задач, що будуються на гіпотезах і вони є настільки різні, наскільки це можливо. У загальному випадку метод k-середніх будує рівно k-різних кластерів, розташованих на якнайбільших відстанях один від одного.

Значення Евклідової відстані між кластерами за методом k-середніх представлено на рис. 4.

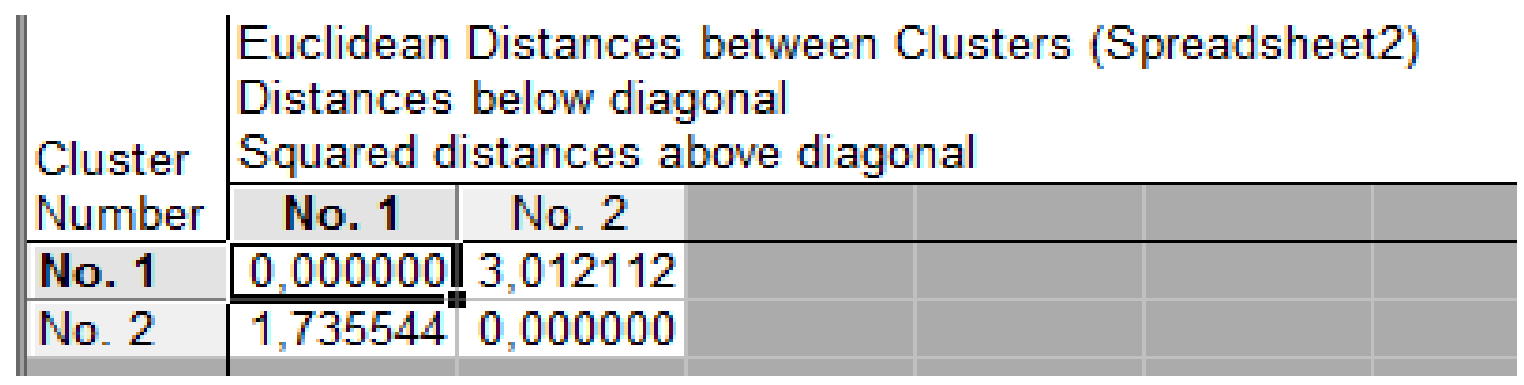

Рис. 4. Значення Евклідової відстані між кластерами за методом k-середніх Джерело: розроблено за допомогою програми «Statistika»

Показником визначення доцільності та узгодженості створених кластерів $\epsilon$ показники групової та міжгрупової дисперсії, результати розрахунку яких представлено на рис. 6.
Побудова кластерів вважаться ефективною та значимою, коли показник групової дисперсії (WithinSS) є меншим за показник міжгрупової дисперсії (BetweenSS). 


\begin{tabular}{|l|c|c|c|c|c|c|}
\multirow{2}{*}{ Variable } & \multicolumn{5}{|l|}{ Analysis of Variance (Spreadsheet2) } \\
\cline { 2 - 8 } & $\begin{array}{c}\text { Between } \\
\text { SS }\end{array}$ & $\begin{array}{c}\text { Within } \\
\text { SS }\end{array}$ & df & F & $\begin{array}{c}\text { signif. } \\
\text { p }\end{array}$ \\
\hline Коеффіцієнт автономії & 7,169350 & 1 & 1,830650 & 8 & 31,33029 & 0,000512 \\
\hline Коефіцієнт фінансового ризику & 6,595157 & 1 & 2,404843 & 8 & 21,93959 & 0,001574 \\
\hline Коефіцієнт маневреності власного капіталу & 6,023901 & 1 & 2,976099 & 8 & 16,19275 & 0,003820 \\
\hline Коефіцієнт фінансового левереджу & 5,513336 & 1 & 3,486664 & 8 & 12,65011 & 0,007436 \\
\hline
\end{tabular}

Рис. 6. Показники групової та міжгрупової дисперсії за методом k-середніх Дюерело: розроблено за допомогою програми «Statistika»

Для практичних та наукових потреб необхідно оцінити роль кожної групи факторів у формуванні варіації. При цьому загальну варіацію досліджуваної ознаки необхідно розкласти на дві складові: систематичну та випадкову. Це можна зробити на основі аналітичного групування, при цьому досліджувана ознака є результативною, а групувальна ознака розглядається як систематичний фактор [3].
Найбільш значимими при побудові та розподілу підприємств на кластери виступив саме коефіцієнт автономії, оскільки значення критерію Фішера за ним $\epsilon$ найбільшими.

Для економічної інтерпретації кожного кластера за усіма параметрами проаналізовано графічне відображення значень кожного параметру для кожного кластеру, що представлено на рис. 7.

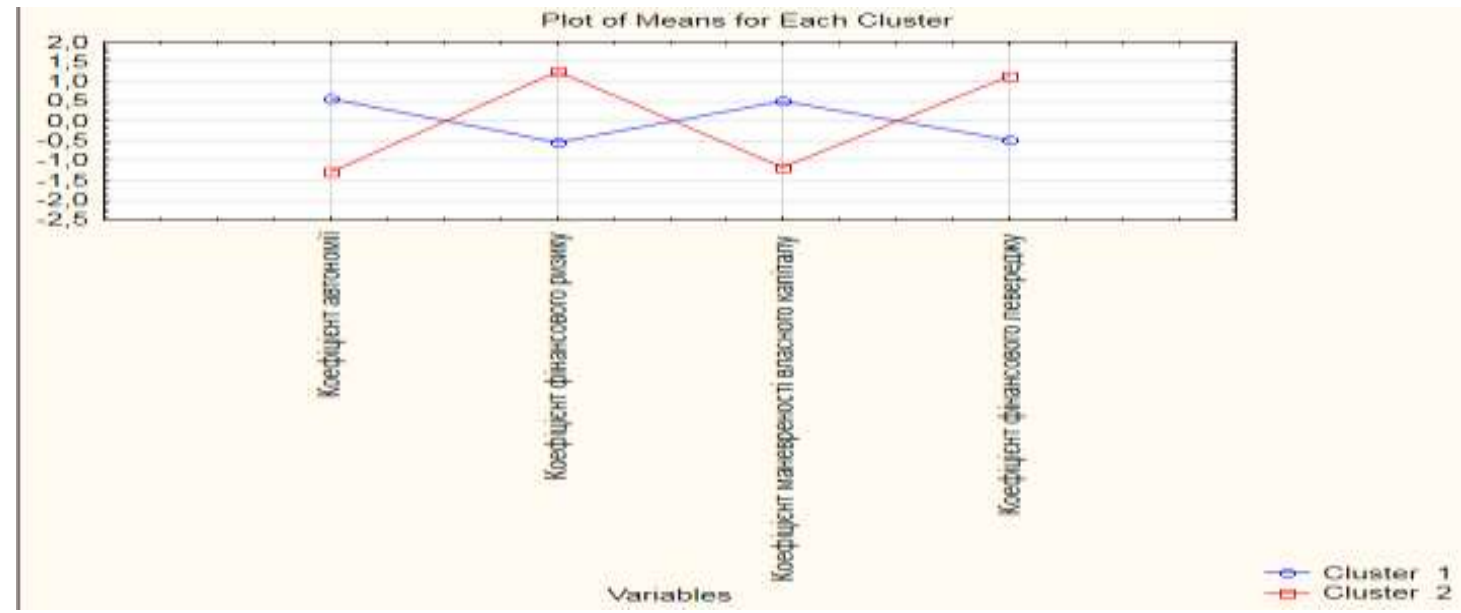

Рис. 7. Графічне відображення значень параметрів для кожного кластеру за методом k-середніх

Джерело: розроблено за допомогою програми «Statistika»

Згідно зданими рис. 8 бачимо, що за методом k-середніх також сформовано два кластери. Можна зазначити, що до першого кластеру увійшли підприємст- ва 3 високими показниками фінансової стійкості, до другого -3 низькими показниками фінансової стійкості, тобто фінансово нестійкі. 


\begin{tabular}{l|r|r|r}
\hline & \multicolumn{3}{|c}{$\begin{array}{l}\text { Descriptive Statistics for Cluster 1 (Spreadsheet2) } \\
\text { Cluster contains 7 cases }\end{array}$} \\
\cline { 2 - 4 } Variable & Mean & $\begin{array}{l}\text { Standard } \\
\text { Deviation }\end{array}$ & Variance \\
\hline Коефіцієнт автономії & 0,554308 & 0,349353 & 0,122048 \\
\hline Коефіцієнт фінансового ризику & $-0,531648$ & 0,097090 & 0,009426 \\
\hline Коефіцієнт маневреності власного капіталу & 0,508102 & 0,041906 & 0,001756 \\
\hline Коефіцієнт фінансового левереджу & $-0,486092$ & 0,028853 & 0,000833 \\
\hline
\end{tabular}

Рис. 8. Описова статистика першого кластеру за методом k-середніх Джерело: розроблено за допомогою програми «Statistika»

Відповідно до даних рис. 8 та 9 ва- сті порівняно 3 нормативними значенгомість коефіцієнтів фінансової стійко- нями та визначено їх дисперсію.

\begin{tabular}{l|r|r|r|}
\hline & \multicolumn{3}{|c}{$\begin{array}{l}\text { Descriptive Statistics for Cluster 2 (Spreadsheet2) } \\
\text { Cluster contains 3 cases }\end{array}$} \\
\cline { 2 - 4 } Variable & \multicolumn{1}{c}{ Mean } & $\begin{array}{l}\text { Standard } \\
\text { Deviation }\end{array}$ & Variance \\
\hline Коефіцієнт автономії & $-1,29339$ & 0,741068 & 0,549182 \\
\hline Коефіцієнт фінансового ризику & 1,24051 & 1,083578 & 1,174142 \\
\hline Коефіцієнт маневреності власного капіталу & $-1,18557$ & 1,217695 & 1,482781 \\
\hline Коефіцієнт фінансового левереджу & 1,13422 & 1,319407 & 1,740835 \\
\hline
\end{tabular}

Рис. 9. Описова статистика другого кластеру за методом k-середніх Джерело: розроблено за допомогою програми «Statistika»

Результати розмежування підпри- риємств, виробників напоїв, до другого ємств за кластерами за методом k- кластеру 3 підприємства. середніх представлено на рис. $10-11$. До першого кластеру віднесено 7 підп-

\begin{tabular}{|l|l|}
\hline & $\begin{array}{l}\text { Members of Cluster Number 1 (Spreadsheet2) } \\
\text { and Distances from Respective Cluster Center } \\
\text { Cluster contains 7 cases }\end{array}$ \\
\cline { 2 - 2 } & Distance \\
\hline ПрАТ «КАРЛСБЕРГ УКРАЇНА» & 0,151696 \\
\hline ПрАТ "ФІРМА "ПОЛТАВПИВО" & 0,193733 \\
\hline ТОВ "Перша приватна броварня "Для людей - як для себе!" & 0,071544 \\
\hline ПрАТ "Уманьпиво" & 0,153648 \\
\hline ПрАТ "МИКУЛИНЕЦьКИЙ БРОВАР" & 0,301834 \\
\hline ПрАТ "Пиво-безалкогольний комбінат"Радомишль" & 0,075956 \\
\hline ПрАТ "Славутський пивоварний завод" & 0,122272 \\
\hline
\end{tabular}

Рис. 10. Склад першого кластеру за методом k-середніх Джерело: розроблено за допомогою програми «Statistika» 


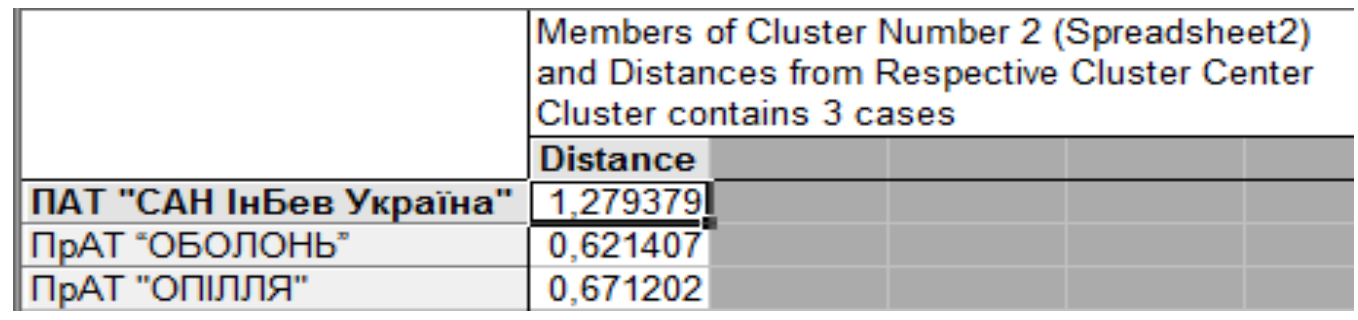

Рис. 11. Склад другого кластеру за методом k-середніх Джерело: розроблено за допомогою програми «Statistika»

Отже, результатами проведеного нами кластерного аналізу за методом kсередніх та за методом Уорда є поділ підприємств на два кластери відносно рівня їх фінансової стійкості. До першого кластеру за здійсненими розрахунками віднесено такі підприємства: ПрАТ «КАРЛСБЕРГ УКРАЇНА», ПрАТ «ФІРМА «ПОЛТАВПИВО», ТОВ «Перша приватна броварня «Для людей - як для себе!», ПрАТ «Уманьпиво», ПрАТ «МИКУЛИНЕЦЬКИЙ БРОВАР», ПрАТ «Пиво-безалкогольний комбінат» Радомишль» та ПрАТ «Славутський пивоварний завод». До другого кластеру увійшли такі підприємства: ПрАТ «АБІНБЕВЕФЕС УКРАЇНА», ПрАТ «ОБОЛОНЬ» ПрАТ «ОПІЛЛЯ» (табл.3).

Таблиця 3

Склад та економічна інтерпретація сформованих кластерів

\begin{tabular}{|c|c|c|}
\hline Показник & Кластер 1 & Кластер 2 \\
\hline Економічна ін- & Підприємства, які є фінансо- & Підприємства, які є фінансово \\
терпретація класте- & $\begin{array}{c}\text { во стійкими, доказом чого } ~ \\
\text { ру }\end{array}$ & $\begin{array}{c}\text { нестійкими, про що свідчить низь- } \\
\text { кий показник автономії (менше } \\
\text { (показник автономії }\end{array}$ \\
\hline
\end{tabular}

Джерело: Складено автором за даними [6]

Отже, розділивши підприємства за кластерами, слід зробити висновок, що до першого кластеру відносяться підприємства, у яких показники фінансової стійкості знаходяться у межах нормативних значень та перевищують їх, до другого кластеру відносяться підприємства, діяльність яких залежить від позикових коштів та має високі показники фінансового ризику, тобто воно має низький рівень фінансово стійкості.
Таким чином, відповідно до проведених результатів аналізу, підприємствам, які віднесено до другого кластеру необхідно покращувати та удосконалювати процес управління фінансовою стійкістю задля досягнення більшої автономності та зниження рівня фінансових ризиків у процесі його подальшого функціонування.

Висновки. Провівши кластерний аналіз підприємств харчової галузі, виробників напоїв, можна зробити висно- 
вки, що вибірка $з$ десяти підприємств поділила результати їх діяльності, а саме за показниками фінансової стійкості, на два кластери. Підприємства, віднесені до першого кластеру, відзначаються найвищими параметрами коефіцієнтів фінансової стійкості, що підтверджено відповідними показниками та розрахунками. Підприємства другого кластеру характеризуються найнижчими показниками фінансової стійкості, їх діяльність надмірно залежить від обсягу залучених коштів та зовнішнього впливу, результатом чого є підвищення рівня фінансового ризику.
Кластерний аналіз дозволяє виділяти групи виробників напоїв (кластери) грунтуючись на показниках фінансової стійкості, що дозволяє виділяти «фінансово стійких» та «фінансово нестійких (проблемних)» підприємств. А тому, застосування кластерного аналізу сприяє оптимізації управлінських рішень, 3 метою своєчасного виявлення загроз зовнішнього та внутрішнього середовища на фінансову діяльність підприємства, а також створює підгрунття для прогнозування результатів діяльності у майбутньому.

\section{Список використаних джерел}

1. Білик М. Д. Бюджетування у системі фінансового планування. Фінанси України. 2011. № 3. С. 97-110.

2. Бандурин В. Зарубежный опыт управлении несостоятельными предприятиями. Антикризисный менеджмент. 2014. № 10. С. 2-13.

3. Bankruptcy prediction using Extreme Learning Machine and financial expertise. Neurocomputing. 2015. Vol. 128. P. 296-302.

4. Забуранна Л. В. Кластерний аналіз підприємств сфери сільського аграрного туризму. Ефективна економіка. 2013. № 1. URL: http://www.economy.nayka. com.ua/?op=1\&z=1718.

5. Кіндрат О. В. Фінансова стійкість - компонентна складова комплексної характеристики фінансового стану підприємства. Збірник науково-технічних праць НЛУУ. 2011. № 21.14. С. 216-222.

6. Ковальчук Н. О. Фінансова стійкість вітчизняних підприємств як передумова їх стабільного функціонування. Економіка та управління підприємствами. 2016. № 11. С. 368-371.

7. Офіційний сайт ПРаТ «АБ ІнБев Ефес Україна» : веб сайт. URL : https://abinbevefes.com.ua/ (дата звернення : 28.05.2020). 
8. Офіційний сайт ПРаТ «Карлсберг Україна» : веб сайт. URL : https://carlsbergukraine.com/ (дата звернення : 28.05.2020).

9. Офіційний сайт ПРаТ «Оболонь» : веб сайт. URL : http://obolon.ua/ua (дата звернення : 28.05.2020).

10. Офіційний сайт ПРаТ «Опілля» : веб сайт. URL : https://opillia.com/ (дата звернення : 28.05.2020).

11. Офіційний сайт ПРаТ «Полтавпиво»: веб сайт. URL: http://www.poltavpivo.com/ru/. (дата звернення : 28.05.2020)

12. Офіційний сайт ПРаТ «Перша приватна броварня. Для людей, як для себе!» : веб сайт. URL : http://ppb.com.ua/ (дата звернення : 28.05.2020).

13. Офіційний сайт ПРаТ «Уманьпиво» : веб сайт. URL : https://umanpivo.ua/ru.

14. Офіційний сайт ПРаТ «Микулинецький Бровар» : веб сайт. URL : https://brovar.org/ (дата звернення : 28.05.2020).

15. Офіційний сайт ПРаТ «Пиво-безалкогольний комбінат. Радомишль» : веб сайт. URL: https://pbkradomyshl.business-guide.com.ua/ (дата звернення : 28.05.2020).

16. Офіційний сайт ПРаТ «Славутський пивоварний завод» : веб сайт. URL : https://starovar.ua/draft-beer-product/9 (дата звернення : 28.05.2020).

17. Смірнова Т. О. Фінансова стійкість підприємства. Науковий вісник НЛТУ. 2011. № 12. С. 196-203.

18. Сухенко Л. В. Фінансова стійкість : економічна сутність та місце в загальній стійкості підприємства. Молодіжний науковий вісник Української академї банківської справи НБУ. 2012. № 1. С. 189-198. 